\title{
The Strangest Cult: Material Forms of the Political Book through Deleuze and Guattari
}

\section{Nicholas Thoburn University of Manchester}

\begin{abstract}
This article investigates the complex object of the political book. Mobilising Deleuze and Guattari's typology of the book, the article assesses the material properties of four specific books (or sets of books): Mao Zedong's 'Little Red Book', Russian Futurist books, Antonin Artaud's paper 'spells', and Guy Debord and Asger Jorn's 'anti-book' Mémoires. Highly critical of the dominant mode of the political book, what they call the 'root-book', Deleuze and Guattari draw attention to the troubling religious structures and passions that order its field. Here the book internalises the world as the origin and source of truth and authority-a mode of existence as dear to the avant-garde as it is to religious formations: 'Wagner, Mallarmé, and Joyce, Marx and Freud: still Bibles.' But the book also features in Deleuze and Guattari's counter-figure of the 'rhizome-book', where they foreground the dynamic materiality of this medium: 'A book has neither object nor subject; it is made of variously formed matters, and very different dates and speeds.' The rhizome-book is an enticing concept for assessing the political book, yet Deleuze and Guattari pay little attention to the specific, concrete attributes of this medium. In focusing on the properties of particular books this article seeks to address that absence, and so contribute to an understanding of the political book that is fully engaged with its material forms.
\end{abstract}

Keywords: the book, rhizome-book, Deleuze and Guattari, Mao Zedong, Russian Futurism, Antonin Artaud, Situationist International

Deleuze Studies 7.1 (2013): 53-82

DOI: 10.3366/dls.2013.0094

(C) Edinburgh University Press www.euppublishing.com/dls 
One can speak out only through the mouth, but the book's facilities for expression take many more forms. (Lissitzky 2000: 135-6)

The place of the media form of 'the book' in the emergence of the political cultures and structures of the modern nation state has been the subject of an important body of research (Eisenstein 1980; Darnton 1996; Febvre and Martin 1997). Considerably less attention has been paid to the place of the book in extra-parliamentary political cultures, or-and this is where my primary interest lies - to political critique of the book's form and function. A rare exception can be found in Deleuze and Guattari's A Thousand Plateaus. In a surprising and singular assessment, here the common understanding of the book as a generic instrument of secular enlightenment is supplanted with an image of the book as a fraught and ambivalent material entity, one entwined with a rather troubling political passion. Highly critical of the dominant mode of the political book and its associated semiotic and subjective patterns, what they call the 'root-book', Deleuze and Guattari develop a set of concepts for a fully materialist understanding of this medium, and point to the possibilities of a counter-figure, the 'rhizome-book'.

As N. Katherine Hayles (2002: 32-3) insists in Writing Machines, the materiality in question is complex and emergent. Materiality is not a fixed property of the book, but a mutable product of its physical, sensory, textual, conceptual, temporal and affective materials and relations. It is well known that a concern with the full complexity of material relations is paramount in Deleuze and Guattari's work. Yet despite their materialist framing of the book-and, with A Thousand Plateaus, their own experiment in the rhizome-book ${ }^{1}$-they pay little attention to the book's concrete forms and materials. Against that tendency to abstraction, this article seeks to keep the book's rich materiality at the centre of discussion, so contributing -in the spirit of contemporary studies in textual materialism and the practitioner field of the artists' book (Hayles 2002; Drucker 2004; Selcer 2010) - to an understanding of the political book that is fully engaged with its material forms. As such, the article at once sets out the contours of Deleuze and Guattari's typology of the book and mobilises it to assesses the material properties of four specific books (or sets of books): Mao Zedong's 'Little Red Book', Russian Futurist books, Antonin Artaud's paper 'spells', and Guy Debord and Asger Jorn's 'anti-book' Mémoires.

Allow me to make a few methodological points before beginning the discussion proper. A reader familiar with the above group of books may already be questioning the wisdom of analysing together such disparate 
works, of which only Mao's book fulfils the conventional criteria of a 'political' book (the others sit more comfortably in the analytic framework of the cultural avant-garde). And one of these sets of books, Artaud's spells, would not under any normal rules of classification even be designated as 'books' at all, for these single-sheet artefacts are closer to letters or artworks on paper. Why, then, have I brought this heterogeneous group together? Well, Mao's book is included principally because it is a paradigmatic case of the political root-book, and a book about which very little has been written, remarkably so given its global impact. The other books analysed here are all selected because they are at once singular experiments in textual inscription and the form of the book, and particularly enticing examples for thinking with the concept of the rhizome-book. The very heterogeneity of the set is of course part of the appeal, for I in no way wish to compose a unified group of rhizomebooks - this set is fundamentally open. Neither do I seek to establish a hard formal boundary between the book and its associated mediums of inscription, not least of which is the letter-hence my inclusion of Artaud's spells. After all, Deleuze and Guattari, as I show, have no objection to breaching the boundaries of the book, or, as is well known, to finding value in the open-ended arrangement of disparate elements. ${ }^{2}$ As for the 'politics' of these works, the point is not whether they are self-identified as 'political books', but how they trouble and overcome the form of the root-book, itself a most political entity.

\section{The Delusional Passion of the Book}

From the first pages of $A$ Thousand Plateaus one encounters a rather unusual typology of three kinds of book: the 'root-book', the 'fascicular root-book' and the 'rhizome-book'. These are tendencies or organising patterns in the field of the book, not mutually exclusive categories; in any particular book one would expect their co-presence and interaction, albeit with varying degrees of prominence. But for Deleuze and Guattari, the dominant tendency, such that it is the 'classical' figure of this medium, is the root-book.

The root-book is a signifying totality, an enclosed and sufficient entity constituted as an image of the world. It is a formation immanent to the sacred texts of Judaism, Christianity and Islam. To limit my discussion to Christian expressions, for Francis Bacon in his 1605 Advancement of Learning, God provided two books: the volume of the Scriptures, which reveals God's will, and the volume of the creatures - the book of nature-which reveals his power (Borges 2000). These books exist in an 
imitative relation of complementarity, where the essential forms found in nature are mirrored in the universal book of Scriptures. Earlier, in his 1550 Primera parte de las diferencias de libros que hay en el universo, Alejo Venegas conceived of the book as an 'ark' and 'depository' of divine knowledge. As Walter Mignolo (2000: 351) explains, for Venegas, 'The human book has two functions: to know the creator of the Universe by reading His Book and, at the same time, to censure every human expression in which the Devil manifests itself by dictating false books.'

The essential structure of the root-book is clearly evident in these foundational expositions of the book. As it creates an imitative image of nature, the book presides, through the law of reflection, over the split between book and world. Severed from the world and, as such, pristine in its spiritual autonomy, the book is also a vector of authority, as is clear in Venegas: the 'ark' of the book both enjoins subjection to God's word and ensures against 'false books'. There is, then, a mundane subject constituted in the book's truth and authority, but it can also develop a peculiar passion, a 'monomania' of 'the book as origin and finality of the world' (Deleuze and Guattari 1988: 127). Deleuze and Guattari (111-48) make this point about the book's passional subjectivity through an assessment of the book's place in the semiotic system they call the 'postsignifying regime of signs'.

I present Chinese Maoism as an example of this postsignifying regime below, but it is useful first to set out its principal characteristics. As analytically (if rarely empirically) distinct from the 'signifying' regime, the postsignifying regime of signs is an 'active' rather than 'ideational' semiotic system. It is characterised less by the endless cycle of interpretation of signs, than by 'concise formulas' conducive to passional, subjective action. The radiating network of signification anchored in centres of interpretive authority (priest, political leader, despot) here breaks down. Instead, local 'points of subjectification' emerge that are constituted through the betrayal of dominant social relations and semiotic codes (Deleuze and Guattari give the example here of the betrayal of food by the anorexic) and a certain monomania that leads the subject on a passional vector through a series of finite linear proceedings, each drawn, as if to a 'black-hole', by the pursuit of its end. The particular semiotic expressions of the passional regime are composed of a 'subject of enunciation' and a 'subject of the statement', where the latter is bound to the utterances of the former and acts in a 'reductive echolalia' as its respondent or guarantor. ${ }^{3}$

It is in the action-oriented formulas of this regime that the book proper emerges, as it moves away from an essentially oral, 'nonbook' character 
with external referent in God or despot, and instead-like a 'portable packet of signs' (Deleuze and Guattari 1988: 122)-comes to internalise the world as the origin and source of truth and authority:

in the passional regime the book seems to be internalized, and to internalize everything: it becomes the sacred written Book. It takes the place of the face and God, who hides his face and gives Moses the inscribed stone tablets.... The book has become the body of passion... It is now the book, the most deterritorialized of things, that fixes territories and genealogies. (Deleuze and Guattari 1988: 127)

As is clear from the Old Testament references, the root-book and its 'delusional passion' is religious in origin, but it is not limited to such formations (Deleuze and Guattari 1988: 127). ${ }^{4}$ Indeed, this 'strangest cult' has been a key feature of avant-garde culture and politics: 'Wagner, Mallarmé, and Joyce, Marx and Freud: still Bibles' (127). Mallarmé's (1971: 690) formulation of the book as 'spiritual instrument'-'all earthly existence must ultimately be contained in a book'-is perhaps the clearest expression of this tendency. But the degree to which Marx is subject to the passional form of the book is questionable; indeed, in The German Ideology Marx himself makes a direct critique of the religious mode of the book that is remarkably resonant with that of Deleuze and Guattari. ${ }^{5}$ Nonetheless, this defence of Marx cannot always be made of Marxism, at least not as expressed in regimes where Marxism became state doctrine. And it is from this milieu that I want to take a specific case of a political root-book.

\section{Mao Zedong's Little Red Book}

It would be difficult to find a book more enmeshed in its immediate environment than Quotations from Chairman Mao Tse-Tung (henceforth, Quotations), otherwise known as the Little Red Book. If it trails considerably behind the Bible in estimated sales figures, the majority of the 900 million copies of the second-best-selling book in world history ${ }^{6}$ were published in a period of under four years, between 1964 and 1967, with the second year of the Cultural Revolution, 1967, accounting for 350 million (Lei Han 2004: 1; MacFarquhar and Schoenhals 2006: 240; Wilkinson 2008: 29). Of course, the Little Red Book was not a cause of the Cultural Revolution, yet - as is indicated by its frequent and central presence in the iconic posters and photographic images of the period -it was an object with a considerable agential role in inspiring, distributing and consolidating the collective passions of that 
upheaval. ${ }^{7}$ These posters and images also speak to the importance of the book as a rich material entity-as does its popular name, which foregrounds less the content or 'quotations' than the physical dimensions of the book, and its colour.

Quotations is principally a means for the transmission of the politicophilosophical system officially known as 'Mao Zedong Thought'. ${ }^{8}$ While Mao's China was comprised of different semiotic regimes (with more than a little despotic signification), Mao Zedong Thought is a clear exemplar of the dynamics of the word and the book in the postsignifying regime of signs. Žižek is not alone in observing a wholly 'cosmic' orientation in Maoism, one that bound the Chinese people and Party to a transcendent trajectory of liberation that Mao's Thought discerned in human and natural history (in Mao Zedong 2007: 10). ${ }^{9}$ This prophetic reflection of the world in Mao's Thought is simultaneously a separation from it, one that protects the 'purity' of the word against the 'ubiquitous contamination' of the everyday world (Lifton 1970: 49). ${ }^{10}$ But, in accord with the passional structure of the root-book, it is a pristine truth that is subsequently returned to the world as authority and action. As such, Mao Zedong Thought constituted the Maoist 'point of subjectification', spiritualising the word as substance, nourishment and energiser of an immortal revolutionary cause. In the language of a 1966 People's Liberation Army newspaper:

The thought of Mao Tse-tung is the sun in our heart, is the root of our life, is the source of all our strength. Through this, man becomes unselfish, daring, intelligent, able to do everything; he is not conquered by any difficulty and can conquer every enemy. (qtd in Lifton 1970: 72)

So configured, this passional subjectivity was to transcend mere individual mortality, as the catastrophe of Mao's Great Leap Forward (1958-62) rather confirms: between 15 and 40 million people died of starvation, over-work and summary killing as Mao sought an ultra-voluntarist route to industrialisation via the super-exploitation of labour, exporting grain during the famine to fund the import of military and industrial technology (Dikötter 2011). This subjective principle is also evident in Mao's words - in this framing of nuclear war, for instance, from a letter to Khrushchev: 'For our ultimate victory, ... for the total eradication of the imperialists, we ... are willing to endure the first [US nuclear] strike. All it is is a big pile of people dying' (Mao, qtd in Chang and Halliday 2007: 505). Such immortal political subjectivity was operational through individual identification with the macro, cosmic orientations of Mao's Thought, but its power was manifest also in its 
ability to function at a micro-level, drawing as Maoism did a set of ethical criteria and associated practices to assess and modulate everyday behaviour.

With these characteristics, it is no surprise that while an early essay by Mao (2007: 44) called to 'oppose book worship', by the time of the Cultural Revolution Mao's books had become elevated to a fount of singular knowledge: 'the best books in the world, the most scientific books, the most revolutionary books' (qtd in Lifton 1970: 72). ${ }^{11}$ Thus sanctified, Mao's texts took on the authoritarian function of the rootbook that we saw above in Venegas, as is apparent in the call of the Communist Party daily, the Red Flag, to 'establish with utmost effort the absolute authority of the great Mao Zedong's Thought', 'Let Mao Zedong's Thought control everything' (qtd in Lu 2004: 65).

If this is the passional subjectivity of Mao's Thought, an important means of its social articulation was the particular structure of Quotations, to which I now turn. Quotations was initially published on a restricted basis in May 1964 under Lin Biao's direction as a vehicle for the education of the People's Liberation Army, which he headed. The book comprised selections of Mao's works under thirty thematic chapters, extending to thirty-three in 1965. This enabled a pedagogical practice characterised by group learning and recitation of passages and slogans, an approach that became central to the book's use following mass publication in 1966. Lin Biao described the benefits of such pedagogy in 1959: 'Learning the writings of Comrade Mao Zedong is the shortcut to learning Marxism-Leninism. Chairman Mao's writings are easy to learn, and once learned can be put to use immediately' (qtd in Yan and Gao 1996: 179-80). With a largely illiterate population such an approach to the 'shortcut' of learning has progressive features, but it is closely associated with authoritarian signifying patterns. As an 'active' rather than 'ideational' semiotic structure, the concise formula of the root-book requires only identification, as interpretation 'gives way to pure and literal recitation forbidding the slightest change, addition, or commentary' (Deleuze and Guattari 1988: 127). So much is clear in the words of one Shanghai newspaper in 1967: 'We must carry out Chairman Mao's instructions whether we understand them or not' (qtd in Robinson 1971: 509).

The passional activation of Quotations was constituted not only in the structure of its content and pedagogical mode, but also in its wider material properties. It is the redness of Quotations that is its most striking and alluring feature. Its red vinyl covers unify the book globally across its translations, perhaps with something of a universal appeal, but 
in China they carried particular semiotic resonance. Already a prominent signifier of prosperity in Chinese culture, red connoted a commitment to Chinese communism, and was elevated into a foundational sign of struggle during the Cultural Revolution. One former Red Guard remembers:

At the time China was engulfed in a permanent red storm.... Chairman Mao was our red Commander-in-Chief. We called ourselves 'his little red devils'. We read and quoted his little red book. Wore his red buttons on our chests. Red Flags. Red armbands. Red blood. Red hearts. ... We could not tolerate anyone who was of a different color. (Rae Yang, qtd in Schrift 2001: 79-80)

In this fashion the redness of Quotations could be experienced as a collective flood of colour. Describing Mao's 1966 sunrise audiences with the Red Guards in Tiananmen Square, one biographer writes: 'Waved in the air, the red covers [of Quotations] made the square resemble a field ablaze with butterflies' (Terrill 1999: 318). But the mass distribution of the compact object of the book-with the rich sensory qualities that are germane to this tactile, portable medium-was such that its compound of redness, struggle and Mao Zedong Thought could also be experienced at an intimate, personal level. The endorsement leaf in Lin Biao's calligraphy contributed to a feeling of intimacy with the book, a feeling no doubt entrenched by the emotional disjunction associated with the subsequent defacement or removal of this page by each owner, following Lin Biao's death and denunciation. ${ }^{12}$ The book could also take part in everyday ritual. At the start of the work and school day, groups would line up in front of Mao's portrait and wave Quotations while giving the 'three respects and three wishes'; the same practices might also take place immediately on waking or before a meal (Lu 2004: 132-3). Rhythmic waving of the book had a place in Maoist dance routines known as 'loyalty dances', and according to Xing Lu (2004: 133-4) there was even a correct manner of holding Quotations at such ceremonies: with the thumb placed in front and fingers behind, the book would be held over the heart to indicate loyalty and boundless love.

I will close discussion of Mao's Quotations by turning to the postsignifying theme of monomania as manifest among the Red Guards, the passional agents of the Cultural Revolution. The properties of the root-book had a specific articulation with the Red Guards' mode of autonomy, an autonomy that was central to the unleashed brutality of the Cultural Revolution, following Mao's call to 'boldly arouse the masses' against the established authorities (CCCCP 1966). ${ }^{13}$ This is the somewhat paradoxical autonomy of the postsignifying mode of 
subjectivity, with its monomania and reductive echolalia. As Lifton (1970: 60-2) argues, the autonomy of the Red Guards was characterised by a rare sense of 'participating in a great moral crusade' and 'of taking matters into their own hands', but in a fashion constituted through a 'totalistic attack upon any signs of the independent (nonMaoist) self'. ${ }^{14}$ Here, not only did the mass-distributed Quotations open a direct line of affective integration between Mao and the population that was unmediated by Party structure, but its 'reject[ion]' of 'intermediaries or specialists' allowed a recoiling of Mao into the masses, the subject of enunciation into the subject of the statement (Deleuze and Guattari 1988: 127). Like a portable packet of signs, Quotations thus provided the Red Guards with a distributed and mobile set of points of passional subjectification and enunciation unmoored from-and in betrayal of - established sources of institutional authority. Mao did not 'hide his face' in the direct sense that Deleuze and Guattari mark as constitutive of the passional regime-11 or 12 million Red Guards came to Beijing for the 1966 rallies with Mao, and his image, as part of the official cult of personality, was famously ubiquitous. Nevertheless, at these occasions Mao rarely spoke beyond a few words - to do otherwise would have been to risk the distributed authority of the passional forces set loose: 'The leader who used to lecture for hours to persuade his followers of the merits of a new policy now merely appeared before them with an upraised hand and a glassy smile' (Terrill 1999: 318).

\section{The Rhizome-Book}

Deleuze and Guattari set out their counter figure of the 'rhizome-book' by returning to the relation between the book and the world. If, as we have seen, the root-book is in a relation of separation and imitation with the world-'The law of the book is the law of reflection'-it is based on a misapprehension of nature: 'How could the law of the book reside in nature, when it is what presides over the very division between world and book, nature and art?' (Deleuze and Guattari 1988: 5). It is a quite different understanding of nature that informs the rhizomebook, a book no longer characterised by a pristine truth in imitative separation from the world, but by an immersive transformation, an 'aparallel evolution of the book and the world' (11). In this sense, the 'book exists only through the outside and on the outside' (4). The rootbook does of course also exist through relations with its outside (as we saw in the Cultural Revolution), but in the rhizome-book the outside is 
no longer structured by the book's spiritual autonomy and truth. Rather, here the outside floods into the book. The book loses its root or unity and becomes a 'rhizome' of prodigious connection, a 'little machine' that plugs into its outside not to reproduce the world in the book's image, but to construct a discontinuous series of intensive states or plateaus (4).

The rhizome-book is, as such, a complex and variable arrangement of heterogeneous materials: 'A book has neither object nor subject; it is made of variously formed matters, and very different dates and speeds' (Deleuze and Guattari 1988: 3). Yet despite these materialist conceptual framings, Deleuze and Guattari offer little significant insight on how the specific material and formal properties of the book might be expressed in the mode of the rhizome-book. This is understandable, given the radically open process that the concept seeks to name. But it has the unfortunate effect of allowing the rhizome-book to feature by default as a rather abstract entity, and not itself something with concrete and various material manifestation. This description of the rhizome-book is indicative: 'The ideal for a book would be to lay everything out on a plane of exteriority ..., on a single page, the same sheet: lived events, historical determinations, concepts, individuals, groups, social formations' (9). For all the powerful evocation here of the immanence of the book to its outside, as material form it features only as a metaphorical 'single page'.

Sceptical readers might at this point respond that the rhizome-book is fundamentally a figure of conceptual production, that this is where its materiality lies, not in any serious or sustained relation to the book's concrete forms. Indeed, this assertion can find some support in Deleuze and Guattari's argument itself, in their concept of the 'fascicular rootbook'. Essentially the botched escape from the root-book, the fascicular root-book has severed its principal root or unity such that it opens out to the world - a world now fragmented and chaotic - but the book persists as an image of that world, compensating for chaos with a supplementary unity in the work, a unity that is perhaps even more powerful for its apparent absence: 'The world has become chaos, but the book remains the image of the world.... A strange mystification: a book all the more total for being fragmented' (Deleuze and Guattari 1988: 6). The concept seems designed precisely to scupper modernist experiments in the form of writing. Joyce is the main example, but William Burroughs's 'cutup' method also illustrates this figure of the book, as does Nietzsche (astonishingly so, given his importance to Deleuze), whose 'aphorisms shatter the linear unity of knowledge, only to invoke the cyclic unity of 
the eternal return' (6). Here the critique of formal experimentation is made in no uncertain terms:

To attain the multiple, one must have a method that effectively constructs it; no typographical cleverness, no lexical agility, no blending or creation of words, no syntactical boldness, can substitute for it. In fact, these are more often than not merely mimetic procedures used to disseminate or disperse a unity that is retained in a different dimension for an image-book. Technonarcissism. (Deleuze and Guattari 1988: 22)

And yet Deleuze and Guattari are not wholly hostile to experimentation with the book's form, for the passage continues:

Typographical, lexical, or syntactic creations are necessary only when they no longer belong to the form of expression of a hidden unity, becoming themselves dimensions of the multiplicity under consideration; we only know of rare successes in this. We ourselves were unable to do it. We just used words that in turn function for us as plateaus. (Deleuze and Guattari 1988: 22)

These quotations make Deleuze and Guattari's own tastes in method amply clear - 'We just used words"15 - but there is no a priori rejection here of intervention in the book's material form. Neither should we expect there to be; if an 'assemblage, in its multiplicity, necessarily acts on semiotic flows, material flows, and social flows simultaneously' (Deleuze and Guattari 1988: 22-3) then it would make no sense to deprive the assemblage of the book the possibility of acting on its material forms. And so, succumbing to their own argument, Deleuze and Guattari do in fact make some brief positive comment on concrete experiments in book form. In developing the concept of the rhizomebook they give some prominence to three modern works on the early thirteenth century Children's Crusades, works that generate a nomadic expression in the flow of narratives, movements and peoples. Here there is definite appreciation of formal innovation. In Armand Farrachi's $\mathrm{La}$ Dislocation, for instance, they note that the 'sentences space themselves out and disperse, or else jostle together and coexist, and ... the letters, the typography begin to dance as the crusade grows more delirious' $(23-4) .{ }^{16}$

The task, then, is to consider the dynamics of the rhizome-book in a way that is attentive not only to the book's conceptual and textual features, but to its full materiality, its heterogeneous 'working of matters' (Deleuze and Guattari 1988: 4). I attempt this below through concrete cases, for it would run counter to the spirit of this most immanent of concepts to either set out universal criteria for the rhizome-book, 
or consider it outside of its empirical expressions. In what follows, each set of books is initially approached, as was Mao's Quotations, through their linguistic structure and/or conceptual content. But against the spiritual autonomy of the word in the root-book, here the word is shown to be enmeshed with diverse materials and oriented toward expression that is not constrained by the semiotics of authority. I place attention on the singular ways the particular books break with the root-book mode-break, that is, with the division between world and book, the book's unity and teleology, and its integrated subjectivities. In the course of discussion I touch on some features of the root-book that I have not thus far considered: its relation to the sensory patterns of the State-form and to the structures of the capitalist commodity. The focus throughout is on how the qualities of the rhizome-book are manifest in the artefact of the book itself, in the context of the aesthetic and political concerns of each book's immediate environment. ${ }^{17}$ Since Deleuze and Guattari provide only minimal tools for the analysis of the book's concrete materiality, I at points draw on concepts that they use to explore material culture in other fields. I would underscore that the books are presented here not as a cumulative account of the emergence of the rhizome-book, but as a variable field of its expression, each book foregrounding one or more aspects of the rhizomatic tendency in the material forms of the book.

\section{Polysensuality and the Russian Futurist Book}

Given the cleavage the root-book enacts with the external world, it is appropriate to start with a set of books within which the physical and sensory properties of matter take centre stage: the Russian Futurist books of the 1910s. In their foundational concepts of 'the self-sufficient word' and 'transreason' ('zaum'), the Russian Futurists (or CuboFuturists, as they are sometimes known) took the word not as a transparent vehicle of truth and communication, but as a polymorphous object, placing emphasis on the phonic, graphic, hieroglyphic qualities of writing. ${ }^{18}$ Here the word as object is unmoored from chains of signification. Instead, phonetic analogy, rhythm, raw verbal material, obscure idioms become the substance and organising principles of expression (Lawton 1988: 13). The transrational word is not without its own kind of passion; in the words of Aleksei Kruchenykh, one of the principal exponents of zaum, this 'not yet frozen' or 'melted language' is fundamentally 'emotional' in tenor, associated with intensive states: 'when the artist wants to convey images not fully defined', 'When 
one loses one's reason (hate, jealousy, rage ...)', 'When one does not need it - religious ecstasy, love' (Kruchenykh, qtd in Markov 1969: 347; Kruchenykh 1988a: 182-3).

So, while in Mao's Quotations the word was abstracted from the world in the purity of Mao Zedong Thought, in Futurist transreason the word is drawn back into its variable material fields. In this one can discern elements of Deleuze and Guattari's (1988: 117) 'presignifying' regime of signs, a regime that 'fosters a pluralism or polyvocality of forms of expression that prevents takeover by the signifier and preserves expressive forms particular to content'. But the important point for my purposes is that this Futurist approach to language is integrated with the form and physicality of the books themselves.

Russian Futurist books were conceived of as active, polysensual objects in a fashion that undoes the root-book cleavage between world and book, as the book itself becomes a vital entity adequate to the rhizomatic movements of the transrational word. This manifests in a number of ways. It is most immediately apparent in the exuberance of materials deployed in these books. Developing from an interest in folk culture, ritual-related art, ideographic text, illuminated manuscripts and the ornate objects of nomadic peoples, Futurist books have a wild tactility about them. In deliberate contravention of the fine-printing tradition of the livre d'artiste, they are often roughly hewn works assembled of cheap, disposable materials - an early example, A Slap in the Face of Public Taste, was famously bound in burlap-and diverse print technologies, including lithographed manuscript, handwriting, linocuts, hectography and rubber stamps. They were not to be read as such, but in all their variability were to 'see, listen to, and feel' (Aleksei Remizov, qtd in Gurianova 2002: 26).

To this polymorphous array of materials there corresponds a specific aesthetic form, one that is manifest against the principal sensory structures of the root-book. The modern book, as it has developed through Gutenberg print culture, intensifies the abstracted optical function at the expense of sensuous complexity. The rigid linear text, uniformity of letterforms, and identical copies produce, in Marshall McLuhan's words, a 'visual technology of uniform time and uniform continuous space in which "cause" is efficient and sequential, and things move and happen on single planes' (qtd in Janecek 2002: 41). This indicates why Deleuze and Guattari also name the root-book the 'State apparatus-book': it not only produces patterns of dogma and authority, as we have seen in Quotations, but it also imparts the striating temporal and territorial sensory patterns of the State-form. 
In contrast to this optical aesthetic, Futurist books have a strong relation to the 'haptic' aesthetic Deleuze and Guattari associate with nomadic art (it is not incidental that a number of the Russian Futurists were heavily influenced by the art forms of the Scythian nomads; Ash 2002). I have noted that these books are most tactile, sensual entities, but the haptic is a mode of vision, an immersive 'close vision' that invests the eye with the property of touch, drawing it into a field that dissolves perspective and is grasped only through a local and variable integration of parts, where 'orientations, landmarks, and linkages are in continuous variation' (Deleuze and Guattari 1988: 493). In Futurist books, the interweaving and merging of image and text, the use of handwriting, transrational flight of sense, graphic wandering of words, unbounded colour, variability of printed materials and fluctuation in rhythm all pull the book away from its striated, optical mode and attract an immersive manner of perception, one that allows for an experience of sensory simultaneity (Gurianova 2002). Gerald Janecek (1984: 117) thus writes of Kruchenykh's work: 'a page of "text" need not be read sequentially in linear time, but can be taken at a glance and absorbed by the same process of free visual exploration used in studying a painting'. It is a disorienting sensory experience of which Kruchenykh (1988b: 76) was well aware: 'We can change objects' weight (the eternal force of gravity), we see buildings hanging in the air and the weight of sounds.'

As can be discerned in Kruchenykh's comment here, the haptic aesthetic combines with a quality of movement. For Deleuze and Guattari, the haptic aesthetic is comprised of a particular kind of 'line', an 'inorganic line' that breaks with the 'organic' mode of representation. Whereas organic representation, through the principle of symmetry, limits variability in repetition by maintaining the domination of a central point with radiating lines (as in star-shaped figures), haptic aesthetic forms express a power of variation, with a 'streaming, spiralling, zigzagging, snaking, feverish line' (Deleuze and Guattari 1988: 499). Art here no longer constructs an organic empathy between representation and human subject, but articulates a different mode of life-the traits, flows, impulses of an elementary life of matter, an 'inorganic life' (498). Now, for Deleuze and Guattari $(398,386)$ this nomadic, inorganic line is associated with certain kinds of mobile objects - jewellery and weaponry; objects that do not 'work' in and for striated space, as do tools, but express variable movement undetermined by the 'gravity' of the Stateform. If Futurist books express a haptic aesthetic, as objects they share also the nomadic quality of movement. For now the itinerant property 
of the medium of the book - this 'most deterritorialized of things'-is no longer articulated with distributed authority (as it was in Mao's Quotations) or with the striated perceptual patterns of the State-form (as is imparted by the Gutenberg book). Rather, like paper jewellery, these 'living entit[ies]' that defy gravity and 'fly out' on publication serve to distribute a feverish, inorganic life of matter. ${ }^{19}$

The Futurist book also raises a challenge to the root-book's linear or teleological relation to the world. As Nina Gurianova (2002) argues, the temporal, spatial and rhythmic dislocations of these books are such that, to employ the name of one of the most accomplished Futurist works, this is a world backwards. But there is still perhaps a danger of the book operating here (in the mode of the fascicular root-book) as an archetype, of 'typographical cleverness' propagating a supplementary unity in the fragmented work. It is important, then, that the undoing of the book's teleological relationship to the world is compounded by another aspect of the Russian Futurist book, the persistent troubling of its own unity, as is especially evident in Kruchenykh's work.

Kruchenykh had something of compulsive passion for publishing and was chiefly responsible for perhaps upwards of 200 publications (Janecek 1984: 112). But it is a passion operative against any principle that would orchestrate a unity or model in the work; true poets, he proclaimed, 'should write on their books: after reading, tear it up' (Kruchenykh, qtd in Markov 1969: 130). This destructive tendency took the somewhat inorganic form of an insistence on 'the necessity and the importance of irregularity in art' (Kruchenykh 1988b: 75). For instance, Worldbackwards-a book of poetry by Kruchenykh and Velimir Khlebnikov, and images by Mikhail Larionov, Natalia Goncharova, Nikolai Rogovin and Vladimir Tatlin-is a highly heterogeneous collection of materials and rhythms. But it is also internally irregular: the order of pages differs between copies; individual lithographed pages vary in the colour and weight of paper; rubber-stamped sheets have inconsistent use of letters and decorative symbols; even the covers of the book -in what is the first example of collage in book design-are inconsistent (Janecek 2002). Kruchenykh was also in the habit of assembling materials across different books-reproducing manifestos and texts in different works, using pages from one book in another, even in one case of publishing a new book, Zaumnik, from an older work, From All Books, simply by adding a newly designed cover (albeit one by Aleksandr Rodchenko) (Janecek 1984: 109). In these peculiar practices the book becomes an interminable arrangement of fragments, a looping movement as pages are assembled and reassembled like the 
discontinuous folds of the most rhizomatic of organs: 'These books ... smell of phosphorous, like fresh brain curls' (Terentyev 1988: 179). ${ }^{20}$

\section{Antonin Artaud's Paper Spells}

In formulating the figure of the rhizome-book, Deleuze and Guattari make use of a concept they famously draw from Antonin Artaud, the 'body without organs'. If the root-book is one tendency in the field of the book, the book 'also has a side facing the body without organs, which is constantly dismantling the organism, causing asignifying particles or pure intensities to pass or circulate' (Deleuze and Guattari 1988: 4). As a body without organs, the rhizome-book undoes the sensory organisation of its subject. The haptic materialism of the Futurist book moved in this direction-breaking as it did with the sensory patterns of the striated optical function - but it is in Artaud's paper 'spells' or 'grisgris $^{21}$ that one finds the most singular concrete experiment in textual matter as body without organs. Artaud sent these epistolary objects from Ireland and the Sainte-Anne Hospital and Ville-Évrard asylum in France in 1937 and 1939 as protective or imprecatory devices to friends, doctors and public figures-seven are known to exist, including one that remained unsent to Hitler. ${ }^{22}$ Composed of writing, pictograms and obscure symbols in ink and coloured crayon, included with letters or sent alone, these spells are scraped, scored, hacked things about which no separation can be made between artefact and text, form and content.

As with Futurist books, these spells are entwined with a particular mode or experience of language, one that Deleuze elucidates in his assessment of surface and depth in the linguistic operations of Lewis Carroll and Artaud. Against the incorporeal linguistic surfaces of Carroll, language for Artaud is carved into the depths of the body. In an experience symptomatic of schizophrenia, the body is an 'involution' of the world around-a 'body-sieve' (Deleuze 1990: 87), a 'membrane of infinite crevices' (Artaud 1988: 87): 'Things and propositions have no longer any frontier between them, precisely because bodies have no surface ... Every word is physical and immediately affects the body' (Deleuze 1990: 86-7). Deleuze elucidates the specific procedures by which Artaud transforms the pain of this corporeal semiotic-for the body/word conjunction is experienced as a wounding assault-into an active relation. In brief, Artaud breaks down language into phonetic elements, converted into 'breath-words' and 'howl-words'. In these, 'all literal, syllabic, and phonetic values have been replaced by values which are exclusively tonic', values which correspond to a disaggregated body, 
a body without organs: 'an organism without parts which operates entirely by insufflation, respiration, evaporation, and fluid transmission' (88).

Now, the important point for my purposes is that Artaud's spells can be understood as artefactual manifestations of this relation between language and body. To borrow from Stephen Barber's (2008: 49) assessment of Artaud's notebooks, the spells are a 'prototype', a 'testingground' for the transformational process of the body without organs. Artaud writes: 'I have the idea to put into operation a new re-assembling of the activity of the human world, idea of a new anatomy. / My drawings are anatomies in action' (qtd in Barber 2008: 67). This operation is at once destructive of the existent body, and a generative practice-a procedure both 'terminal' and 'insurgent' (54). And it takes the paper not as a mediating vehicle, but a material immanent to its procedures; in these spells Artaud constructs a paper body without organs. Let us see how.

Writing in 1947, Artaud conceived of his spells as exorcisms performed on the 'objective inertia' of the page (Artaud, qtd in Ho 1997: 19), on its striating, organising gradients: 'The goal of all these drawn and coloured figures was to exorcise the curse, to vituperate bodily against the exigencies of spatial form, of perspective, of measure, of equilibrium, of dimension' (Artaud 1996: 42). No inert support for the written word, then, the sheet of paper is fully a part of the procedure. Like a 'body-sieve', the spell emerges as a dynamic membrane, a field of forces: sign, colour, word, lettering, combine with the material of the paper, perforated and frayed with burns, to produce 'a surface that is as much active as acted upon' (Beaumelle 1996: 40). And it is, too, a corporeal surface. Artaud performs incantation in the spells' construction, as he incises, perforates and burns the page. In this way, signs are captured and held with the force of bodily gesture, so preventing signifying circulation, depriving the word of 'its power to draw together or to express an ... ideational event distinct from its present realization' (Deleuze 1990: 87).

The subject undone on the body-sieve of the paper is not only its author, but its audience too. Agnès de la Beaumelle (1996: 39) describes the spells as 'graphic expulsions', artefacts intended to act physically upon their interlocutors, to have an immediate and disaggregating sensory effect. In Paule Thévenin's words:

Writing no longer has as its sole function that of transmitting a message or a thought; rather, it must act by itself and physically. Everything is studied, 
calculated so as to strike the eye, and through it the sensitivity, of the person for whom the spell is destined ... We can scarcely look at these objects without being contaminated by their vehemence ... (Thévenin, in Derrida and Thévenin 1998: 15, 17)

A trace of this vehement contamination can perhaps be gained from Beaumelle's evocative presentation of the 1939 spells from the VilleÉvrard asylum:

their imprecatory violence now resides more in the physical state of the missive than in the words. Inscribed with a thick ink crayon in purple, the different signs (crosses, stars, triangles, spirals in the shape of serpents, the cabalistic significance of which Artaud knew well) proliferate in all directions, invade the center of the paper itself, break the continuous thread of writing drawn with the same ink crayon: fragments of writing and drawn pictograms henceforth form one body. Not only that: knots, amorphous clusters of crayon, seem to respond in counterpoint, proceeding from the same charge of aggression, to the holes produced by burning the paper (the edges of which are also ravaged); and traces of violent shades of yellow, blue, and red (Artaud also knew the symbolism of colors: these are the colors of death) intensify by their physical presence the imprecatory force of the words. These are no longer simple votive letters but true magical objects, to be handled while making ritualistic gestures ..., which can 'illuminate themselves', like 'gris-gris'. (Beaumelle 1996: 40)

The medium of the letter served Artaud's spells well, for the intimate affect germane to this mode of textual communication is compounded by the letter's fragmentary and impermanent form. If the Futurist book introduced the 'worldbackwards' into the teleological field of the book's political unity and authority, Artaud's (1996: 33) spells also refuse existence as a coherent and enduring work: 'These are not drawings / they figure nothing, / disfigure nothing, / are not there to / construct / edify / establish / a world.' The spells are fragments, their audience - the addressees of these artefacts delivered by post-was limited and temporary, and they exist, in their asubjective affects, only at the edge of destruction: 'And the figures that I thereby made were spells - which, after so meticulously having drawn them, I put a match to' (Artaud 1996: 42).

\section{The Anti-Book of Mémoires}

The last case I will consider emerges from an expressly communist environment; as such it allows me to consider the material properties of the rhizome-book through a more overtly political lens. There is 
considerable justification for Guy Debord's (1993) claim that his and Asger Jorn's 1959 work, Mémoires, was an 'anti-book'. Comprised of text and image fragments assembled by Debord from disparate media and sources, and Jorn's structural lines, splashes and planes of colour, it is at once a memoir of Debord's pre-Situationist milieu around the Lettrist International, an exercise in the techniques of détournement and dérive, and an unworking of its own points of identification, meaning and narrative coherence. The book famously embodies its destructive valence in its binding of heavy sandpaper. But more than the violent impact on the books against which it is placed, the striking effect of the sandpaper covers is the way that when handled they foreground in a heightened sensory fashion the book's physical form and external relations, an enforced appreciation of the book's outside that is complemented by the almost translucent, rather fragile pages encountered within. ${ }^{23}$

The critical impact of Mémoires on the material field of the book includes two aspects that I have not directly considered in the rhizomebooks discussed so far: a critique of capital and the commodity, and a challenge to the specifically activist mode of the root-book's subject. As with Artaud's spells and the Russian Futurist books, Mémoires breaks with the prevailing mode of communication, but it does this from a position specifically attentive to the function of language in capitalist social relations. As Frances Stracey (2003) highlights, language for the Situationist International (SI) was bound up with an emergent cybernetic mode of production, one that integrated signification with command in an 'informationist' paradigm that sought to eradicate all linguistic redundancies and ambiguous signals: a 'universal language' of which, '[s]ince its advent, the triumphant bourgeoisie has dreamed' (Khayati, in Knabb 1981: 171). ${ }^{24}$ More succinctly: 'Words work' (SI, in Knabb 1981: 114). There is a striking relation here with Deleuze's (1995:175) critique of the place of 'universals of communication' in contemporary 'societies of control', with their distributed and continuous systems of regulation: 'speech and communication have been corrupted. They're thoroughly permeated by money - and not by accident but by their very nature'.

For Deleuze, politics cannot resist this situation with an alternative communication - a 'counter-information' (Deleuze 2006: 322) or a 'democratic conversation' (Deleuze and Guattari 1994: 99)-since what is required is a breach in the very modes of subjectivity and exchange constituted in communicational systems. As for the Situationists, they found a breach in the informationist paradigm through the method of détournement. This reuse of existing semiotic and aesthetic materials 
in new ensembles seeks, in Jorn's words, a 'devaluation' of received patterns of meaning (Jorn, in Knabb 1981: 55). The association with the category of political economy, 'value', is not accidental, for this was a devaluation of language to match that of social production more widely: 'Words will not cease to work until people do' (Khayati, in Knabb 1981: 175). In a détournement, the new ensemble derives its 'peculiar power' from holding together trace associations of the devalued elements with the new senses created (SI, in Knabb 1981: 55). But it is in the essential and persistent wrenching of language from the paradigm of information that the force of this first step toward a "literary communism' resides: 'It is not "the nadir of writing" but its inversion. ... [W] hen it uses existing concrete concepts it is simultaneously aware of their rediscovered fluidity, their necessary destruction' (Debord and Wolman, in Knabb 1981: 11; Debord 1983: $\$ 204, \$ 205$ ).

Tom McDonough (2007: 8) makes an astute observation that the destructive orientation to language in détournement necessarily troubles the favoured textual medium of the avant-garde-it can establish no unique and unified work in the manner of the 'Mallarméan Book'. The works of détournement are of a different order, and Mémoires is one of these, comprised as the title page notes 'entirely of prefabricated elements'. ${ }^{25}$ Constituted of usurped and devalued words, Debord and Jorn's book removes the possibility of a distinct and self-expressive authorial subject, a move all the more powerful for its apparent location in the genre of autobiography. The referential object of the book, Debord's milieu of the early 1950s, is similarly undone as a coherent world or political subject, something itemised and foreclosed in linear historical memory. Structured around three dated chapters, moments of the history of the Lettrist International come into focus at points, but it is an unstable and virtual historical field, a field charged with potential, comprised, as the first page warns, 'of lights, of shadows, of figures', 'full of discord and dread'. ${ }^{26}$

The technique of devaluation does not only operate here in the redeployment of existing semiotic materials, but also in their singular instantiation on the pages of the book. As the SI journal later noted of Mémoires, 'the writing on each page runs in all directions and the reciprocal relations of the phrases are invariably uncompleted' (SI, in Knabb 1981: 56). Such indeterminacy is compounded by the cumulative effect of the book, with concepts and meanings coming in and out of focus as they resonate, accumulate and dissipate across its pages. This is not only an effect of language, but is accentuated by the dramatic pattern and spatialisation of the work, structured by Jorn's variously 
lulling, violent and vertiginous sheets of vibrant colour (Stracey 2003). It should be underscored - and it is an astonishing achievement - that in the midst of these intensive, disorienting characteristics, Mémoires maintains a conceptual rigour and force, one that is found not in the conventional form of philosophical demonstration but in a kind of conceptual performance (Banash 2002). The book is not only an exercise in détournement, it invites the reader to engage with it in the manner of a dérive, a surrender of subjective will-to-meaning in the temporal flow and layered, non-linear spatial structure of its pages.

The anomalous character of Mémoires is furthered by the nature of its relation to the structure of the commodity. The commodity form of the book is a feature strangely absent from Deleuze and Guattari's assessment, as if on this matter they succumbed to the obfuscating power of the root-book. The book is a commodity that is especially effective at hiding its commercial nature, its capitalist form obscured by its apparently universal value as a transcendent intellectual, moral and aesthetic good (Striphas 2009). It is as if the generic capitalist power of commodity fetishism - to produce an autonomous artefact severed in people's minds from its socio-material relations - is given a boost by the spiritual power of the root-book, the two conjoining in something of a perfect commodity. For despite appearances, these industrial 'goods which pretend not to be goods at all' (Travis 1999) have been entwined with the emergence and development of the commodity form. The book was not only instrumental in the division of intellectual and manual labour that lies at the heart of capitalist abstract labour, but was itself the first standardised and iterable mass-produced commodity, the book industry being a prime mover in the division of labour, the hourly wage, new technologies, consumer credit and privatisation of language through copyright-and it remains today fully enmeshed in the latest industrial and technological developments (Anderson 1983; Febvre and Martin 1997; Striphas 2009). ${ }^{27}$

In this realm of the commodity, Mémoires has unsurprisingly become something of a rare item, changing hands today for upwards of US $\$ 4,000$. But in its time, this anti-book had an intrinsic anticommodity orientation. The abrasive material of the sandpaper covers seems to defy the commodity values of smooth industrial production and circulation. ${ }^{28}$ Of course, this quality could indicate a different circuit of commercial value, that of the livre d'artiste or artwork proper. It is significant, then, that Mémoires was not created to be sold, but to be a splendid or excessive gift, a 'potlatch'-an anti-productive expenditure based not on scarcity but abundance, and one that intensifies (rather 
than obfuscates) social relations. ${ }^{29}$ In his preface to the 1993 reedition, ${ }^{30}$ Debord explains:

Thus for thirty-five years my Mémoires were never put on sale. Their celebrity comes from only having been given out in the form of the potlatch: that is to say of the sumptuous gift, challenging the other party to give something more extreme in return. (Debord 1993)

If gift economies break with commodity circulation, they can introduce social relations that are themselves constraining, as the gift serves to bind and consolidate relations of obligation (Mauss 1990). And it is clear that the circulation of printed matter had an important role in maintaining the interpersonal and organisational relations of the SI (Wark 2009). But this is only part of the story, for the excess affect or intensity associated with the gift-circulation of Mémoires was not primarily directed toward securing a political community, public or subject. The patterns of association of the root-book-with its orientation toward establishing integrated subjectivity within its regimes of truth and authority - find no presence in Mémoires, which in this sense we might characterise as something of an anti-manifesto:

This anti-book was only offered to my friends, and no-one else was informed of its existence. 'I wanted to speak the beautiful language of my century.' I wasn't too worried about being heard. ... I proved my sober indifference to public opinion straight away, because the public were not even allowed to see this work. (Debord 1993)

Debord's wilful disregard here of a fundamental feature of the political book has a somewhat aristocratic air to it, but it is by no means an apolitical move. Indeed, one can interpret this statement as an aspect of what Banash (2002) considers to be the most radical feature of Mémoires, the breach it enacts in the easy transformation of conceptual and aesthetic production into instrumental 'activist' practice. For here the disaggregating property of the rhizome-book-approached thus far in the form of the Futurist 'worldbackwards' and Artaud's unproductive body without organs - has a direct impact upon the communist thematic of organisational subjectivity. Interpreted in relation to this thematic, Debord's refusal to sanction the book's existence and circulation on the activation of a public establishes Mémoires as an aesthetic expression of the SI's anti-vanguardism. Mémoires aborts its unity as a concentrated bloc of semiotic and organisational authority, all the better to affirm distributed, emergent and self-critical composition as the proper object of communist politics. ${ }^{31}$ 


\section{Conclusion}

What does Deleuze and Guattari's typology of the book enable us to say about the political book? It requires that people of the political book recognise, and extract themselves from, the essentially religious structures and passions that regulate the book's field. Each time the book declares its unique truth and total access to the world, the concept of the root-book invites us to consider how this truth is created from a cleavage with the world, one that constitutes a spiritual dogma that is returned to the world as authoritarian passion. This approach suggests that we explore such formations with attention to the full materiality of the book, even if Deleuze and Guattari do not do so themselves. I have done this here with Mao's Quotations. Mao's book is a wholly material entity, but its material qualities-colour, portability, textual structure - feed into, and are governed by, the book's spiritual autonomy and authoritarian regimes of truth.

If the political book is to break with this root-book structure, it needs a different relation to matter, a relation Deleuze and Guattari approach through the concept of the rhizome-book. This concept is useful not so much as a mechanism of classification, but for what it encourages us to see in the experimental field of the political book. As such, it is best approached through the properties of specific books, in their rich 'working of matters'.

It is possible to set out some shared characteristics of the rhizomebooks considered here. In these works, language is unmoored from signifying chains and dogmatic compulsions, be that in the mode of $\mathrm{Fu}$ turist transrational sensory blocs, Artaud's howl-words, or Debord and Jorn's devalued informational patterns. And this language is enmeshed with variable material fields in a remodelling of the object of the book: as a haptic sensory arrangement of eclectic printed materials, as a dynamic membrane of body-sieve paper, as an anti-book of appropriated materials, non-linear structures and virtual images. Just as the material world floods into these books, breaching their split with nature, so also is the book's subject undone, most radically in Artaud's paper spells, which operate as involutions of body and word in sheets of sensory intensity. Each set of books, too, undoes the book's teleological authority and coherence: a 'worldbackwards' of irregular and refolded materials, a fragment put to fire, an anti-manifesto with inoperative public.

Yet it is also clear that these books emerged from singular political and aesthetic contexts and problematics. In Mémoires, for instance, the conjunction of communication and authority is approached explicitly as 
a dimension of capital, unlike in the other works considered here, and this book's disruptive properties are a unique aesthetic expression of the communist critique of the vanguard party. These situated variations are such that the concept of the rhizome-book cannot describe a cumulative set or itemised aggregate of appropriate techniques. To take seriously Deleuze and Guattari's (1988: 4) peculiar 'taste for matter' requires that the concept operate immanently to the concrete field it surveys. In any concrete field of the book one would expect the interaction of both root and rhizome tendencies. The books considered in this article push either tendency to extremes, so indicating the singular possibilities and variations of the political book, but even here one could no doubt also find aspects of the opposing tendency, especially if they were considered in relation to their wider communities of consumption - there is nothing exhaustive about my treatment.

To conclude, the political book emerges from the works considered in this article as a highly complex entity, where politics is operative in the book's concepts and textual content, as one expects, but also in its passions and authority, and its physical, sensory, temporal and spatial properties. If radical politics concerns transformation of the very conditions of being - not the 'mere political' change against which Engels posits communism proper - then evaluation of these latter properties is as important as attending to the book's more overt political expressions (Marx and Engels 1973: 12). Indeed, it is attention to the breadth of the book's materiality that has enabled me to argue that some of the most apparently political aspects of the book can often be its most troubling.

\section{Notes}

1. 'We are writing this book as a rhizome. It is composed of plateaus.... To attain the multiple, one must have a method that effectively constructs it' (Deleuze and Guattari 1988: 22).

2. It appears that Deleuze's philosophical irreverence toward the book also had a practical dimension: his advice for an 'intensive' way of reading includes 'tearing the book into pieces' (1995: 8-9) and Dosse (2010: 357) reports that in order to avoid carrying an unwieldy stack of books to Vincennes, 'Deleuze would rip out the pages he needed for his class'.

3. For further discussion of the semio-politics of monomania, see Thoburn 2008.

4. In his critique of Eurocentric formulations of 'the book' as a universal standard entwined with the history of colonial subjugation, Mignolo (2000) similarly argues that the integration of religious authority with the book is less a particular manifestation of this medium than its historical condition of emergence.

5. For Marx and Engels, Max Stirner's The Ego and its Own functions as 'the perfect book, the Holy Book'. It posits 'the history of the kingdom of the unique [that] follows a wise plan fixed from eternity', a plan based on the egoist's 
'delirious fantasy', in Stirner's words, of 'the world as it is for me' (Marx and Engels 1976: 117, 126).

6. The Bible is estimated at 5-6 billion copies and the Quran at 800 million (Wilkinson 2008: 29).

7. Mao himself commented on the power of Quotations in a 1966 letter to his wife, Jiang Qing, albeit while expressing an irritation with Lin Biao's role: 'I have never believed ... that those little books of mine could have such fantastic magic, yet he blew them up, and the whole country followed' (Mao, qtd in Terrill 1999: 370). A large collection of Chinese posters of this period, many featuring Quotations, can be viewed at < http://chineseposters.net/ > (last accessed 17 January 2011).

8. Mao Zedong Thought is at once constituted in the detail of Mao's philosophy and is its unifying, passional dimension. I have taken the latter, the signifying structure of Mao Zedong Thought, to be the principal 'content' of Quotations. Save for one or two comments, I do not have space here to analyse the book's particular textual content.

9. The cosmic vector of Mao's world-view is amply evident in two of the most popular texts of the Cultural Revolution period, 'Serving the People' (included in Quotations) and 'The Foolish Old Man who Removed the Mountains'.

10. Quotations is liberally peppered with the trope of purity and corruption. For instance, of the practice of 'criticism and self-criticism' Mao writes that it 'prevents all kinds of political dust and germs from contaminating the minds of our comrades and the body of our Party' (Mao Tse-Tung 1966: 260). The relation between the purity of Mao Zedong Thought and its worldly field of manifestation is clear also in Mao's 1958 assessment of the apparent advantages of the 'poor and blank' condition of the peasantry: 'A clean sheet of paper has no blotches, and so the newest and most beautiful words can be written on it' (Mao, qtd in Schram 1989: 128).

11. The source of Lifton's quotation is not given.

12. The power of the word is accentuated in Chinese culture by the ideographic form of Chinese characters and the expressive art of calligraphy. The text itself reads: 'Study Chairman Mao's writings, follow his teachings and act according to his instructions.'

13. Contrary to some trends in current philosophy after Alain Badiou, I take it as read that the Cultural Revolution was the result of a split in the governing class of a demagogic state capitalist regime, as Mao sought to reassert his authority (and, ultimately, his labour-intensive route to industrialisation) following the disaster of the Great Leap Forward. For a remarkably astute communist analysis in this vein, published a year or so after the upheaval began, see Knabb 1981: 185-94.

14. The autonomy of these young Maoists was expressed more widely in their nomadic movement across the country in the 'exchange of revolutionary experience', and in the popular violence that was endemic to the Cultural Revolution, following such injunctions as 'Beat to a pulp any and all persons who go against Mao Zedong Thought', and 'Long live the red terror' (to quote Red Guard wall posters from two elite middle schools in Beijing; qtd in MacFarquhar and Schoenhals 2006: 104, 126).

15. It is because $A$ Thousand Plateaus constructs its rhizome qualities in this way primarily through words and concepts alone that I do not consider it as an object of study in this article, where my interest lies in books that explicitly and extensively engage with the formal and physical properties of the medium. In any case, much has been written already about the 'plateau' and rhizome structure of A Thousand Plateaus, and while I in no way wish to deny its astonishing 
rhizomatic dimensions, it would be a mistake in this book's own terms to elevate it to a unique model around which a class of rhizome-books should ever be arrayed.

16. Another work, Absolument nécessaire. The Emergency Book by Joëlle de La Casinière (1973), is credited in a footnote as 'a truly nomadic book' (Deleuze and Guattari 1988: 520). They make no further comment, but it is a work of graphic poetry and montage, expressive of the itinerant lifestyle and artpractice of its author. As Casinière (2011: 3) reports, Deleuze arranged for the publication of the work after she sent him a photocopy of the manuscript, though once it was published he remarked that he preferred the 'pale and poorly made photocopy' to the finished book. See < http://www.montfaucon.eu $>$ for images of a complete edition (last accessed 17 January 2011). I am grateful to Joëlle de La Casinière for sharing information about this book with me.

17. A complementary approach would be to pursue the set of mutable relations that any one book forms with its social milieu, since the social effects and situated appropriations of books are of course central to their materiality. But I reject the notion that this basic position of Deleuze-inspired research bars one from using Deleuze to discuss the form of particular entities in a degree of isolation; certainly, Deleuze himself was happy to partake of the latter approach, as is evident from his close analysis of specific paintings or cinematic works. The complementarity of these approaches is clear in Daniel Selcer's (2010) excellent text, Philosophy and the Book.

18. The most comprehensive account of the movement, one that should not be confused with Italian Futurism, is Markov 1969. Images of complete editions of a number of Russian Futurist books can be viewed at < http://www.getty.edu/ research/conducting_research/digitized_collections/russian_avant-garde/pdfs. html $>$ (last accessed 17 January 2011).

19. The first quotation here is Gurianova's $(2002: 25,27)$ characterisation of the Futurist understanding of the book; the second she takes from advertisements for Futurist editions.

20. Gurianova (1999: 110) argues in related terms that 'these republications confirmed ... the right to "incompleteness", and presumed ever new readings, continuous renewal, and the metamorphic nature of creation'.

21. 'Gris-gris', the noun Artaud uses for these works, signifies charm, fetish or amulet.

22. Six of Artaud's spells are reproduced in Rowell 1996. Deleuze and Guattari (1988: 164) assess the spell for Hitler as a 'BwO intensity map' of thresholds and waves, but they limit comment to its textual content and make no reference elsewhere to Artaud's spells.

23. This binding was proposed by the Danish printer Verner Permild, of the firm Permild and Rosengreen who also printed Jorn and Debord's earlier book-work, Fin de Copenhague. Permild was responding to Jorn's request for a binding of unconventional material - perhaps sticky asphalt or glass wool - that would leave some residue or otherwise affect the reader's hands (Nolle 2002).

24. It is worth noting that the SI also level the critique of the 'informationist' mode of language at the orthodox Left. Khayati (in Knabb 1981: 173) discusses the 'Bolshevik order' of the 'more or less magical, impersonal expressions', 'inflexible' and 'ritual formulas' that work in the image of the State to preserve its 'purity' and 'substance' in the face of obviously contradictory facts.

25. Even the degraded photographs of Debord's comrades and drinking companions are purloined from a photo-romance book on the Left Bank scene. Debord later noted that one brief phrase was his own.

26. For an enticing interpretation of the first page of Mémoires, see Banash 2002. 
27. The reader will have noticed that the books explored here are all from pre-digital times. I discuss the material forms and politics of digital publishing in Thoburn 2012.

28. This commodity-defiance is also intrinsic to the irregular form of the Russian Futurist book, where it has an additional valence as part of the Russians' more or less direct challenge to the commodity aesthetics of speed and industry in Italian Futurism.

29. It seems that the book was not entirely abstracted from commercial economies, for it had a place in financing the SI's activities. In a letter to the German Situationist Uwe Lausen, Debord (1962) proposes that Lausen sell copies of Mémoires to fund the publication of Der Deutsche Gedanke, noting that its 'full price... is very high'. On the contradictions involved in financing the group, see Knabb 1981: 142. I explore the anti-commodity capacities of printed matter further in Thoburn 2010. For discussion of the affective politics of the gift, see McDonough 2007: 148-54.

30. The commercial republication of Mémoires raises questions I am unable to address here, but I take it as given that the reprint is a very different entity to the 1959 work discussed in this article.

31. If the SI's anti-vanguardism is articulated in Mémoires, this tendency was always in tension with Debord's more autocratic inclinations. For a nuanced discussion of these tendencies in the SI and the Scandinavian Situationist groups, see Slater 2001.

\section{References}

Anderson, Benedict (1983) Imagined Communities: Reflections on the Origin and Spread of Nationalism, New York: Verso.

Artaud, Antonin (1988) 'From The Nerve Meter (1925)', in Antonin Artaud: Selected Writings, ed. Susan Sontag, trans. Helen Weaver, Berkeley: University of California Press, pp. 79-87.

Artaud, Antonin (1996) '50 Dessins pour assassiner la magie', trans. Richard Sieburth, in Margit Rowell (ed.), Antonin Artaud: Works on Paper, New York: MoMA, pp. 32-7.

Ash, Jared (2002) 'Primitivism in Russian Futurist Book Design 1910-14', in Margit Rowell and Deborah Wye (eds), The Russian Avant-Garde Book 1910-1934, New York: MoMA, pp. 33-40.

Banash, David (2002) 'Activist Desire, Cultural Criticism, and the Situationist International', Reconstruction: Studies in Contemporary Culture, 1:2, $<$ reconstruction.eserver.org/021/Activist.htm > (last accessed 17 January 2011).

Barber, Stephen (2008) Antonin Artaud: Terminal Curses, London: Solar Books.

Beaumelle, Agnès de la (1996) 'Introduction', trans. Jeanine Herman, in Margit Rowell (ed.), Antonin Artaud: Works on Paper, New York: MoMA, pp. 39-41.

Borges, Jorge Luis (2000) 'On the Cult of Books', in Jerome Rothenberg and Steven Clay (eds), A Book of the Book, New York: Granary Books, pp. 347-50.

Casinière, Joëlle de La (1973) Absolument nécessaire. The Emergency Book, Paris: Minuit.

Casinière, Joëlle de La (2011) 'Email interview/April 2011', with Andrew Bonacina, < http://dl.dropbox.com/u/32871722/Exhibitions/2011/Casiniere/Casiniere\%20 Interview.pdf $>$ (last accessed 21 September 2011).

Central Committee of the Chinese Communist Party (1966) 'Decision Concerning the Great Proletarian Cultural Revolution', 8 August 1966, < http://www. rrojasdatabank.org/16points.htm $>$ (last accessed 17 January 2011). 
Chang, Jung and Jon Halliday (2007) Mao: The Unknown Story, London: Jonathan Cape.

Darnton, Robert (1996) The Forbidden Best-Sellers of Pre-Revolutionary France, London: HarperCollins.

Debord, Guy-Ernest (1959) Mémoires, Paris: L'Internationale situationniste.

Debord, Guy (1962) 'Letter to Uwe Lausen, 9 September 1962', trans. Not Bored!, < http://www.notbored.org/debord-9September1962.html $>$ (last accessed 17 January 2011).

Debord, Guy (1983) Society of the Spectacle, Detroit: Black and Red.

Debord, Guy (1993) 'Attestations: Preface to the Second Edition of Mémoires (October 1993)', trans. Reuben Keehan, < http://www.cddc.vt.edu/ sionline/postsi/attestations.html $>$ (last accessed 17 January 2011).

Deleuze, Gilles (1990) The Logic of Sense, trans. Mark Lester with Charles Stivale, ed. Constantin V. Boundas, New York: Columbia University Press.

Deleuze, Gilles (1995) Negotiations: 1972-1990, trans. Martin Joughin, New York: Columbia University Press.

Deleuze, Gilles (2006) Two Regimes of Madness, ed. David Lapoujade, trans. Ames Hodges and Mike Taormina, New York: Semiotext(e).

Deleuze, Gilles and Félix Guattari (1988) A Thousand Plateaus: Capitalism and Schizophrenia, trans. Brian Massumi, Minneapolis: University of Minnesota Press.

Deleuze, Gilles and Félix Guattari (1994) What is Philosophy?, trans. Graham Burchell and Hugh Tomlinson, New York: Verso Books.

Derrida, Jacques and Paule Thévenin (1998) The Secret Art of Antonin Artaud, trans. Mary Ann Caws, Cambridge, MA: MIT Press.

Dikötter, Frank (2011) Mao’s Great Famine, London: Bloomsbury.

Dosse, François (2010) Gilles Deleuze and Félix Guattari: Intersecting Lives, trans. Deborah Glassman, New York: Columbia University Press.

Drucker, Johanna (2004) The Century of Artists' Books, New York: Granary Books.

Eisenstein, Elizabeth L. (1980) The Printing Press as Agent of Change, Cambridge: Cambridge University Press.

Febvre, Lucien and Henri-Jean Martin (1997) The Coming of the Book: the Impact of Printing 1450-1800, trans. David Gerard, New York: Verso Books.

Gurianova, Nina (1999) 'A New Aesthetic: Word and Image in Russian Futurist Books', in Alla Rosenfeld (ed.), Defining Russian Graphic Arts: from Diaghilev to Stalin, 1898-1934, New Brunswick: Rutgers University Press, pp. 97-120.

Gurianova, Nina (2002) 'A Game in Hell, Hard Work in Heaven: Deconstructing the Cannon in Russian Futurist Books', in Margit Rowell and Deborah Wye (eds), The Russian Avant-Garde Book 1910-1934, New York: MoMA, pp. 24-32.

Hayles, N. Katherine (2002) Writing Machines, Cambridge, MA: MIT Press.

Ho, Christopher (1997) 'Antonin Artaud: From Centre to Periphery, Periphery to Centre', Performing Arts Journal, 19:2, pp. 6-22.

Janecek, Gerald (1984) The Look of Russian Literature: Avant-Garde Visual Experiments, 1900-1930, Princeton: Princeton University Press.

Janecek, Gerald (2002) 'Kruchenykh contra Gutenberg', in Margit Rowell and Deborah Wye (eds), The Russian Avant-Garde Book 1910-1934, New York: MoMA, pp. 41-9.

Knabb, Ken (ed.) (1981) Situationist International Anthology, trans. Ken Knabb, Berkeley: Bureau of Public Secrets.

Kruchenykh, A. (1988a) 'Declaration of Transrational Language', in Anna Lawton (ed.), Russian Futurism through its Manifestoes, 1912-1928, trans. Anna Lawton and Herbert Eagle, Ithaca: Cornell University Press, pp. 182-3. 
Kruchenykh, A. (1988b) 'New Ways of the Word', in Anna Lawton (ed.), Russian Futurism through its Manifestoes, 1912-1928, trans. Anna Lawton and Herbert Eagle, Ithaca: Cornell University Press, pp. 69-78.

Lawton, Anna (ed.) (1988) Russian Futurism through its Manifestoes, 1912-1928, trans. Anna Lawton and Herbert Eagle, Ithaca: Cornell University Press.

Lei Han, Oliver (2004) 'Sources and Early Printing History of Chairman Mao's Quotations', < http://www.bibsocamer.org/BibSite/Han/index.html > llast accessed 17 January 2011).

Lifton, Robert Jay (1970) Revolutionary Immortality: Mao Tse-tung and the Chinese Cultural Revolution, Harmondsworth: Penguin.

Lissitzky, El (2000) 'From “Our Book”, in Vladimir Mayakovsky and El Lissitzky, For the Voice, Cambridge, MA: MIT Press, pp. 134-7.

Lu, Xing (2004) Rhetoric of the Chinese Cultural Revolution, Columbia: University of South Carolina Press.

McDonough, Tom (2007) 'The Beautiful Language of My Century': Reinventing the Language of Contestation in Postwar France, 1945-1968, Cambridge, MA: MIT Press.

MacFarquhar, Roderick and Michael Schoenhals (2006) Mao's Last Revolution, Cambridge, MA: Harvard University Press.

Mallarmé, Stéphane (1971) 'The Book: A Spiritual Instrument', trans. Bradford Cook, in Hazard Adams (ed.), Critical Theory Since Plato, New York: Harcourt Brace Jovanovich, pp. 674-6.

Mao Tse-Tung (1966) Quotations from Chairman Mao Tse-Tung, Peking: Foreign Languages Press.

Mao Zedong (2007) Slavoj Žižek Presents Mao on Practice and Contradiction, London: Verso Books.

Markov, Vladimir F. (1969) Russian Futurism: A History, London: University of California Press.

Marx, Karl and Frederick Engels (1973) Manifesto of the Communist Party, Beijing: Foreign Languages Press.

Marx, Karl and Frederick Engels (1976) Collected Works Volume 5, London: Lawrence and Wishart.

Mauss, Marcel (1990) The Gift: The Form and Reason for Exchange in Archaic Societies, trans. W. D. Halls, London: Routledge.

Mignolo, Walter (2000) 'From "Signs and their Transmission: the Question of the Book in the New World"', in Jerome Rothenberg and Steven Clay (eds), A Book of the Book, New York: Granary Books, pp. 351-71.

Nolle, Christian (2002) 'Books of Warfare: The Collaboration between Guy Debord and Asger Jorn from 1957-1959', Vector, < virose.pt/vector/b_13/ nolle.html > (last accessed 17 January 2011).

Robinson, Thomas W. (ed.) (2001) The Cultural Revolution in China, Berkeley: University of California Press.

Raowell, Margit (ed.) (1996) Antonin Artaud: Works on Paper, New York: MoMA.

Schram, Stuart (1989) The Thought of Mao Tse-Tung, New York: Cambridge University Press.

Schrift, Melissa (2001) Biography of a Chairman Mao Badge, New Brunswick: Rutgers University Press.

Selcer, Daniel (2010) Philosophy and the Book: Early Modern Figures of Material Inscription, London: Continuum.

Slater, Howard (2001) 'Divided We Stand: An Outline of Scandinavian Situationism', Infopool no. 4, London and Copenhagen: Infopool.

Stracey, Frances (2003) 'Surviving History: A Situationist Archive', Art History, 26:1, pp. 56-77. 
Striphas, Ted (2009) The Late Age of Print: Everyday Book Culture from Consumerism to Control, New York: Columbia University Press.

Terentyev, Igor (1988) 'From Kruchenykh the Grandiose', in Anna Lawton (ed.), Russian Futurism through its Manifestoes, 1912-1928, trans. Anna Lawton and Herbert Eagle, Ithaca: Cornell University Press, pp. 178-81.

Terrill, Ross (1999) Mao: A Biography, Stanford: Stanford University Press.

Thoburn, Nicholas (2008) 'What Is a Militant?', in Ian Buchanan and Nicholas Thoburn (eds), Deleuze and Politics, Edinburgh: Edinburgh University Press, pp. 98-120.

Thoburn, Nicholas (2010) 'Communist Objects and the Values of Printed Matter', Social Text, 28:2, pp. 1-30.

Thoburn, N. (2012) 'Ceci n'est pas un magazine: The Politics of Hybrid Media in Mute Magazine', New Media and Societv, 14:5, pp. 815-31.

Travis, Trish (1999) 'Ideas and Commodities: The Image of the Book', MIT Communications Forum, < web.mit.edu/comm-forum/papers/travis.html $>$ (last accessed 17 January 2011).

Wark, McKenzie (2009) 'The Secretary', in Guy Debord, Correspondence: The Foundation of the Situationist International (June 1957-August 1960), trans. Stewart Kendall and John McHale, Los Angeles: Semiotext(e), pp. 5-27.

Wilkinson, Carl (2008) The Observer Book of Books, Reading: Observer Books.

Yan, Jiaqi and Gao Gao (1996) Turbulent Decade: A History of the Cultural Revolution, trans. Daniel W. Y. Kwok, Hawaii: University of Hawaii Press. 